\title{
MULTIMEDIA INTERAKTIF BERBASIS KARAKTER SEBAGAI UPAYA PENINGKATAN NILAI-NILAI KARAKTER DAN KEMAMPUANBERPIKIR TINGKAT TINGGI
}

\author{
Page 7 Interactive Multimedia Based On Character as Efforts to Improve The Value Of Character \\ and The High Order Thinking Skills \\ Johan Syahbrudin \\ Universitas Pamulang, Tangerang Selatan \\ johansyahbrudin@gmail.com
}

\begin{abstract}
Abstrak - Tantangan kurikulum 2013 dan pembelajaran abad XXI berkaitan erat dengan pendidikan karakter, teknologi, dan kemampuan berpikir tingkat tinggi atau high order thinking skills (HOTS).Pengembangan dan penggunaan teknologi dalam pembelajaran berupa multimedia interaktif yang membelajarkan nilai-nilai karakter dan pemikiran tingkat tinggi peserta didik masih sangat perlu untuk dilakukan.Berdasarkan hasil pada setiap uji yang dilakukan, multimedia hasil pengembangan ini dinyatakan layak dan efektif digunakan sebagai sumber sekaligus media pembelajaran untuk meningkatkan kemampuan berpikir tingkat tinggi.Nilai-nilai karakter yang terkandung dalam multimedia ini sudah disajikan dengan baik.Program hasil pengembangan ini tidak sampai pada pengujian keefektifan peningkatan nilai karakter, akan tetapi dengan adanya program ini diharapkan dapat merangsang dan memotivasi peserta didik dalam menumbuhkan nilai-nilai karakter sesuai jati diri bangsa Indonesia.
\end{abstract}

Kata kunci - Multimedia Interaktif, Nilai Karakter,danHOTS.

Abstract - The challenges of the 2013 curriculum and the learning of the XXI century are closely related to character education, technology, and high-order thinking skills (HOTS). The development and use of technology in the learning of interactive multimedia that membelajarkan values of characters and high-level thinking of learners is still very necessary to do. Based on the results of each test conducted, multimedia development results are declared feasible and effective use as a source and learning media to improve the ability of high-level thinking. The character valuescontained in this multimedia are well presented. Program development results are not up to testing the effectiveness of the increase in the value of the character, but with the existence of this program is expected to stimulate and motivate the students to foster the values of character according to the Indonesian national identity.

Keywords - Interactive Multimedia, Character Values, and HOTS.

\section{PENDAHULUAN}

Ada banyak tujuan pembelajaran sesuai kurikulum 2013 dan tuntutan pembelajaran abad XXI, baik itu yang berkaitan dengan pemanfaatan teknologi pembelajaran, pendidikan karakter, maupun peningkatan kemampuan berpikir tingkat tinggi.

Pendidikan karakter menjadi sorotan utama bangsa kita saat ini.Pasalnya karena mulai memudarnya nilai-nilai karakter yang seharusnya menjadi ciri khas bangsa Indonesia.Nilai-nilai karakter yang dimaksud berdasarkan hasil penelitian Mukhibat (2012) di antaranya adalah nilai kabajikan religius, jujur, disiplin, tanggung jawab, kerja keras, toleransi, cinta damai, peduli lingkungan sosial, dan patriotisme.
Salah satu upayaperbaikan kualitas pendidikan karakter sesuai sistem pendidikan nasional, di antaranya dengan peningkatan kualitas media pembelajaran, terutama media yang memanfaatkan perkembangan teknologi.

Akan tetapi, media pembelajaran yang digunakan di Indonesia cenderung masih sebatas fasilitas untuk memudahkan pendidik dalam menyampaikan materi-materi pelajaran yang orientasinya pada peningkatan kemampuan kognitif peserta didik.Media pembelajaran yang digunakan juga merupakan hasil dari pengembangan yang sifatnya untuk peserta didik secara umum yang belum tentu sesuai dengan karakteristik atau kondisi peserta didik tertentu, sehingga menyebabkan ketidakefektifan dari penggunaan media tersebut. 
Selain itu, masih jarang media pembelajaran yang dilengkapi dengan permasalahan untuk mengajarkan peserta didik dalammenumbuhkan nilai-nilai karakter sesuai jati diribangsa Indonesia yang tercinta ini.

Oleh karena itu, perlu adanya pengembangan Page | 8 media atau bahkan multimedia pembelajaran yang tidak hanya sebatas fasilitas untuk memudahkan guru, tetapi juga mengajarkan kemampuan kognitif dan nilai-nilai karakter yang dirancang sesuai kebutuhan, potensi sumber daya dan kondisi lingkungan masing-masing peserta didik.Dengan diterapkannya multimedia semacam ini baik sebagai media maupun salah satu sumberpembelajaran, diharapkan peserta didik dapat belajar dengan lebih mudah dan efisien, sehingga salah satu upaya untuk meningkatkan kualitas peserta didi dalam segi kognitif dan karakter diharapkan dapat terlaksana dengan baik.

Terkait dengan tujuan pembelajaran berikutnya berupa peningkatan kemampuan berpikir tingkat tinggi, tentu perlu mengkaji tentang pembelajaran keterampilan berpikir.Pembelajaran keterampilan berpikirharus diintegrasikan dan menjadi bagian dari pembelajaran sehari-hari dengan cara membantu dan memfasilitasi peserta didik untuk menjadi problemsolveryang baik. Untuk itu, pendidikperlu memfasilitasi peserta didik dengan berbagai permasalahan yang menuntut peserta didik menggunakan keterampilan berpikir tingkat tingginya.

Akan tetapi, pembelajaran yang melatih keterampilan berpikir tingkat tinggi memiliki beberapa kendala.Salah satunya adalah peranan pendidik di sekolah yang masih dominan(teacher center learning).Kendala lainnya adalah masih sedikitnya media pembelajaran yang memfasilitasi peserta didik dengan berbagai fenomena ataukasus yang menuntut mereka untuk menjadi pemecah masalah (problemsolver) yang lebih baik.Selain itu juga,sistem penilaian kemampuan prestasi peserta didik lebih banyak didasarkan melalui tes-tes yang sifatnya menguji kemampuan kognitif tingkat rendah, seperti soal-soal ujian sekolah maupun ujian nasional sebagai standar kelulusan mereka.Oleh karenanya, perlu juga dikembangkannya soal-soal tes yang dapat mengukur kemampuan tingkat tinggi peserta didik.

Menilik dari beberapa permasalahan tersebut, dirasa perlu adanya pengembangan multimedia pembelajaran sebagai salah satu upaya untuk meningkatkan kualitas pendidikan di Indonesia, baik dari segi peningkatan kemampuan berpikir tingkat tinggi maupun peningkatan nilai-nilai karakter sesuai ciri khas bangsa. Multimedia yang dimaksud tentunya harus interaktif, memuat uraian materi, ilustrasi fenomena atau kasus maupun soal-soal latihan yang menampilkan nilai-nilai karakter dan menuntut pemikiran tingkat tinggi dalam pemecahannya. Dan melalui penggunaan multimedia ini, proses pembelajaran diharapkan menjadi lebih menarik dan sangat disenangi oleh peserta didik karena sesuai dengan kondisi dan kebutuhan mereka, terlebih lagi jika multimedia yang digunakan berbasis karakter dan menuntut pengguna untuk mengembangkan kemampuannya untuk berpikir tingkat tinggi.

\section{A. Multimedia Interaktif}

\section{LANDASAN TEORI}

Multimedia berasal dari dua kata, "multi" dan "media".Multi berarti banyak, sedangkan media berarti sarana atau perantara.Multimedia juga bisa didefinisikan sebagai alat untuk penyampaian isi/konten yang ada di dalamnya (Asyhar, 2011). Sedangkan Susilana \& Riyana (2007) mengemukakan bahwa modul multimedia interaktif merupakan alat atau sarana pembelajaran yang berisi materi, metode, batasan-batasan, dan cara mengevaluasi yang dirancang secara sistematis dan menarik untuk mencapai tujuan pembelajaran yang diharapkan.

Jadi secara sederhana, multimedia interaktif merupakan perpaduan berbagai media (seperti suara, teks, gambar, animasi, grafik, dan video) yang bersifat interaktif (saling mempengaruhi atau ada hubungan timbal balik antara pengguna dan media) yang dirancang secara sistematis dan menarik untuk menyampaikan informasi atau isi pembelajaran sesuai dengan materi, metode, dan batasan-batasan tertentu (tujuan pembelajaran yang diharapkan).

Penggunaan multimedia interaktif telah banyak terbukti memberikan dampak positif dalam suatu pembelajaran.Seperti hasil penelitian Sanjaya (2016) yang menyatakan bahwa kelompok belajar yang menggunakan multimedia interaktif merasa sangat puas dan peningkatan hasil belajarnya lebih besar jika dibandingkan kelompok yang tidak menggunakan multimedia interaktif.

\section{B. Nilai Karakter}

Nilai merupakan sesuatu yang dianut oleh individu ataupun masyarakat dan diyakini kebenarannya sebagai salah satu acuan untuk berprilaku dalam kehidupan sehari-hari.Nilai juga merupakan acuan dan pendorong dalam kehidupan seseorang dalam bertindak (Muhtadi, 2004).Oleh karena itu, nilai-nilai ini harus ditumbuhkembangkan melalui suatu pendidikan agar tercipta individu-individu yang baik budi pekertinya.Pendidikan seperti inilah yang disebut sebagai pendidikan karakter.Jadi pendidikan karakter merupakan upaya untuk mengenalkan dan menginternalisasikan nilai-nilai positif kepada seseorang (dalam hal ini peserta didik) agar menjadi pribadi-pribadi yang senantiasa berprilaku terpuji.

Tujuan pendidikan karakter adalah untuk menumbuhkan integritas moral seorang individu dalam kehidupan bermasyarakat, di mana setiap pendekatannya melibatkan pendidikan nilai sesuai 
ciri khas masyarakat masing-masing, dengan prinsip dasarnya yaitu membelajarkan seluruh keutamaan nilai suatu masyarakat tanpa pengecualian.

Dan di Indonesia sendiri, ada nilai-nilai ideal yang perlu dikembangkan melalui pendidikan karakter itu sendiri, yaitu: nilai-nilai agama, nilai Page |9 budaya dan nilai-nilai yang terkandung dalam Pancasila. Menurut Mukhibat (2012) "Pendidikan karakter dalam sistem pendidikan nasional lebih mencerminkan paham obsulote moral dari pada relativism moral.Paham absolute moral ini dapat dilihat pada diangkatnya nilai-nilai Pancasila sebagai sumber pendidikan karakter, sehingga nilai dalam Pancasila baik secara politis dan yuridis telah menjadi kesepakatan bersama. Adapun dua sumber nilai yang lain yakni agama dan budaya lebih berlaku paham pluralitas moral (bukan relativism moral), di mana pendidik dan praktisi pendidikan dapat mengurangi atau menambah nilai-nilai yang sejalan dengan masyarakat. Pendidikan karakter yang seperti itulah yang bisa dikatakan sebagai sesuatu yang otentik atau khas pendidikan karakter Indonesia." Dan berdasarkan hasil penelitian Mukhibat (2012), nilai yang dianggap layak untuk dikembangkan dalam pendidikan karakter kepada peserta didik baik melalui pemaksaan maupun pembiasaan yakni nilai kabajikan religius, jujur, disiplin, tanggung jawab, kerja keras, toleransi, cinta damai, peduli lingkungan sosial, dan patriotisme.

Jadi, pendidikan karakter yang menjadi ciri khas pendidikan karakter Indonesia di antaranya adalah nilai kabajikan religius, jujur, disiplin, tanggung jawab, kerja keras, toleransi, cinta damai, peduli lingkungan sosial, dan patriotisme.

\section{Kemampuan Berpikir Tingkat Tinggi}

Peter Reason (Wina Sanjaya, 2006) menyatakan bahwa berfikir (thingking) merupakan suatu proses aktif yang tidak hanya sekedar mengingat (remembering) dan memahami (comprehending). Hal itu juga bisa dsebut sebagai kemampuan berfikir tingkat tinggi, yang sesuai dengan versi Anderson (2001) meliputi: menganalisis (analyze, C4) merupakan menguraikan sekaligus mengaitkan suatu permasalahan ke dalam sub-sub permasalahan; mengevaluasi (evaluate, C5); dan mencipta (create, C6), yaitu mengkreasikan pengetahuan lama menjadi suatu gagasan baru. Seperti yang disampaikan oleh Rofiah, dkk. (2013), bahwa kemampuan berpikir tingkat tinggi bukan sekedar proses berpikir untuk menghafal dan menyampaikan kembali informasi yang telah diketahuinya, tetapi jugamenguraikan, menghubungkan, dan mengkreasikan pengetahuan dan pengalamannya untuk menentukan keputusan dan memecahkan suatu permasalahan.

Sedangkan Krathwohl (2002) menyatakan bahwa indikator untuk mengukur kemampuan berpikir tingkat tinggi meliputi: (1) Menganalisis (menganalisis informasi yang masuk dan menguraikannya menjadi bagian-bagian untuk mengenali pola hubungannya, menganali hubungan sebab-akibat dari suatu skenario yang rumit, dan mengidentifikasi/merumuskan pertanyaan); (2) Mengevaluasi (menilai suatu solusi, gagasan, dan metodologi sesuai standar keefektivannya; membuat hipotesis, mengkritik dan melakukan pengujian; dan menerima atau menolak suatu pernyataan berdasarkan kriteria yang telah ditetapkan; dan (3) Mengkreasi (menggeneralisasikan suatu ide atau cara pandang terhadap sesuatu; merancang cara untuk menyelesaikan masalah; dan mengorganisasikan unsur-unsur menjadi struktur baru yang orisinil.

Jadi, kemampuan berpikir tingkat tinggi atau yang biasa disebut high order thinking (HOT) merupakan proses mental seseorang dalam hal menganalisis, mengevaluasi, dan menciptakan suatu ide baru yang dengan cara menata dan mengkaitkan informasi baru dengan pengetahuan yang telah dimiliki menjadi struktur baru yang orisinil. Sehingga dengan kemampuan ini, seseorang dapat menganalisis dan memutuskan apa yang dipercaya dan harus dilakukan, membuat prediksi, memecahkan masalah, dan mengkreasikan atua bahkan menciptakan ide baru.

\section{Multimedia Interaktif Berbasis Karakter \\ Multimedia interaktif berbasis karakter} merupakan perpaduan berbagai media dan bersifat interaktif (saling mempengaruhi atau ada hubungan timbal balik antara media dan penggunanya) yang dirancang secara sistematis dan menarik untuk menyampaikan informasi atau isi pembelajaran dengan memadukan nilai-nilai karakter yang tertuang dalam isi materi, contoh-contoh soal, maupun soal latihan untuk mencapai tujuan pembelajaran yang diharapkan.

Nilai-nilai karakter yang dimaksud di sini adalah yang menjadi ciri khas pendidikan karakter Indonesia itu sendiri, yaitu nilai kabajikan religius, jujur, disiplin, tanggung jawab, kerja keras, toleransi, cinta damai, peduli lingkungan sosial, dan patriotisme.

\section{METODE PENELITIAN}

Penelitian ini menggunakan pendekatan penelitian dan pengembangan, , dengan orientasi untuk mengembangkan dan memvalidasi produkproduk hasil pengembangan tersebut.

Model pengembangan yang digunakan yaitu model 4-D (Thiagarajan, Semmel dan semmel) yang terdiri dari 4 tahap, di antaranya:Define (pendefinisian) meliputi analisis media, materi, dan nilai-nilai karakteryang perlu dibelajarkan sesuai dengan tujuan pembelajaran dan kebutuhan peserta didik;Design(perancangan) meliputi pemilihan media, pemilihan format, dan desain awal multimedia;Develop(pengembangan)meliputi 
pengembangan dan uji coba produkoleh ahli dan pengguna; dan Disseminate (penyebaran) yaitu dengan diterapkan pada sekolah sebagai media maupun salah satu sumber pembelajaran.

Ada dua jenis data dalam penelitian pengembangan ini, yaitu data kualitatif dan data

Page|10 kuantitatif.Data kualitatif diperoleh melalui observasi, wawancara, studi pustaka, dan hasil pengisian angket respon penguji terhadap multimedia yang dikembangkan, sedangkan data kuantitatif diperoleh melalui tes.Observasi dan wawancara digunakan untuk mengidentifikasi kebutuhan pembelajaran, karakteristik peserta didik, análisis pembelajaran, dan análisis kebutuhan topik.Studi pustaka digunakan untuk menganalisis nilai-nilai karakter dan spesifikasi multimedia yang perlu dikembangkan.Instrumen angket ketika pengujian oleh ahli digunakan untuk mengumpulkan data sekaligus acuan revisi terkait kelayakan produk berdasarkan kesesuaian desain / tampilan multimedia, aspek pembelajaran, isi/materi pembelajaran, dan nilai-nilai karakter yang terkandung dalam produk yang dikembangkan.Instrumen angket respon pengguna digunakan untuk mengumpulkan data sekaligus acuan revisi terkait kemenarikan, kemudahan, dan kemanfaatan produk.Instrumen tes digunakan untuk mengetahui tingkat keefektifan produk dalam aspek peningkatan kemampuan tingkat tinggi peserta didik.

\section{PEMBAHASAN}

Ada banyak cara yang dapat digunakan untuk mencapai tujuan pembelajaran yang berkaitan dengan peningkatan kemampuan berpikir tingkat tinggi dan peningkatan nilai-nilai karakter peserta didik. Salah satunya melalui penggunaan multimedia interaktif berbasis karakter yang dikembangkan sesuai kebutuhan, potensi sumber daya dan kondisi lingkungan masing-masing peserta didik.

Pembelajaran dengan memanfaatkan multimedia interaktif berbasis karakter yang mengandung uraian materi, ilustrasi fenomena atau kasus, maupun soal latihan yang menampilkan nilainilai karakter yang menjadi ciri khas bangsa Indonesia (nilai kabajikan religius, jujur, disiplin, tanggung jawab, kerja keras, toleransi, cinta damai, peduli lingkungan sosial, dan patriotisme), selain dapat menghindari ketidaktepatan karena dirancang sesuai kebutuhan, potensi sumber daya dan kondisi lingkungan masing-masing, juga proses pembelajaran menjadi lebih menarik dan sangat disenangi oleh peserta didik.

Di dalam multimedia yang dikembangkan juga menuntut penggunanya untuk mengembangkan kemampuan berpikir tingkat tinggi, karena uraian materi yang ada di dalamnya tidak langsung menyajikan materi secara utuh, tetapi melalui proses-proses analisis, dan dilanjutkan dengan evaluasi isi materi, dan mengkreasikan pengetahuan yang telah didapatkannya.

Hasil utama dari penelitian dan pengembangan ini adalah multimedia interaktif pada materi kinematika gerak lurus SMP/MTs yang terdiri atas dua bagian pokok yaitu pembuka dan pilihan menu.Adapun salah satu tampilan dalam bagian pembuka ditunjukkna pada Gambar 1 berikut.

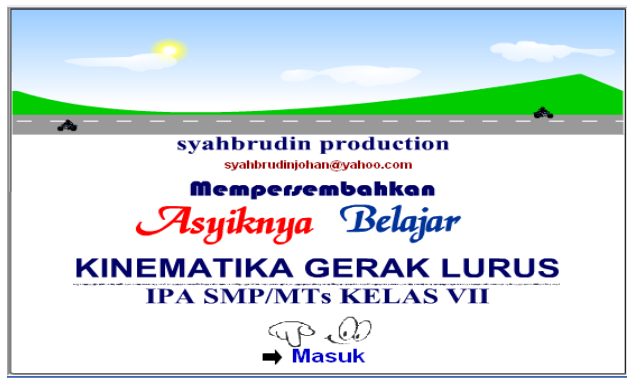

Gbr 1. Tampilan pembuka multimedia

Beberapa tampilan yang mengajarkan nilai karakter ditunjukkan pada Gambar 2.

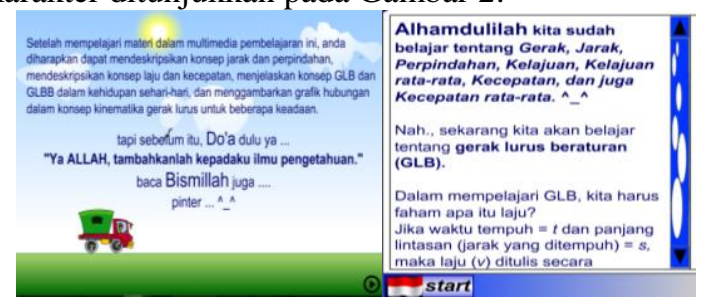

Gbr 2.Beberapa contoh tampilan pembelajaran nilai karakter

Sedangkan tampilan pertama dalam pilihan menu ditunjukkan pada Gambar 3 berikut.

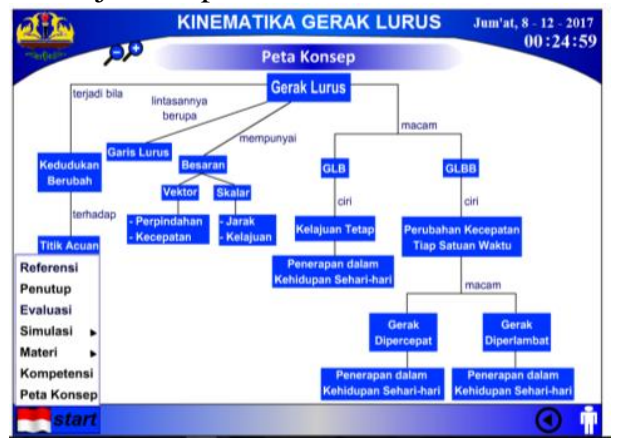

Gbr 3. Tampilan pertamapilihan menu

Pembuatan program multimedia ini dilakukan dengan menggunakan perangkat keras (laptop) dan perangkat lunak (macromedia flash) melalui beberapa tahapan. Adapun secara rinci hasil dari setiap tahapan prosedur penelitian dan pengembangan yang telah dilakukan adalah sebagai berikut:

1) Define (pendefinisian), pada tahap awal ini dilakukan studi pustaka, observasi, dan wawancara dengan beberapa siswa di SMP 
Negeri 2 Trimurjo guna mengetahui kebutuhan program, pemilihan materi, dan karakteristik pengguna. Berdasarkan tahap define ini diperoleh data bahwa perlunya peningkatan nilai-nilai karakter dan kemampuan berpikir tingkat tinggi, masih sangat terbatasnya sumber

Page|11 dan media pembelajaran yang tersedia, pembuatan dan/atau penggunaan program seperti multimedia interaktif pada pelajaran fisika, khususnya materi kinematika gerak lurus belum banyak dilakukan oleh guru sebagai sumber dan/atau media pembelajaran dikarenakan oleh beberapa faktor, sementara siswa sangat antusias akan adanya variasi pembelajaran dengan menggunakan berbagai media, pun juga dengan adanya praktikum langsung maupun dengan menggunakan virtual laboratory.

Nilai-nilai karakter seperti nilai kabajikan religius, jujur, disiplin, tanggung jawab, kerja keras, toleransi, cinta damai, peduli lingkungan sosial, dan patriotisme masing sangat perlu untuk ditingkatkan. Hal itu terbukti dengan masih seringnya siswa yang bolos pelajaran, mencontek ketika ujian, kurang tanggung jawab dalam mengerjakan tugas atau pekerjaan rumah yang diberikan, pernah melakukan perkelahian di sekolah, begitu mudah mencuri buah-buahan milik warga di sekitar sekolah.

Untuk dapat memecahkan permasalahan tersebut, maka dikembangkan multimedia interaktif berbasis karakter yang berisi berbagai media berupa teks, gambar, grafik, animasi, video, interaktif yang dirancang secara sistematis dan menarik dengan memadukan nilai-nilai karakter (seperti nilai kabajikan religius, jujur, disiplin, tanggung jawab, kerja keras, toleransi, cinta damai, peduli lingkungan sosial, dan patriotisme) yang tertuang dalam isi materi, contoh-contoh soal, maupun soal latihan untuk mencapai tujuan pembelajaran yang diharapkan.

2) Design(perancangan), setelah diperoleh data terkait kebutuhan program, materi, dan karakteristik pengguna pada tahap define, dilanjutkan dengan membuat naskah/desain materi pembelajaran.Pembuatan naskah/desain materi dilakukan melalui tiga tahap, yaitu identifikasi materi berdasarkan BSNP, desain cara penyajian nilai karakter, dan desain simulasi yang dihasilkan. Kegiatan identifikasi materi dan uraian pembelajaran dilakukan untuk mengetahui dan membuat peta konsep/materi, peta kompetensi, jabaran isi/materi pembelajaran, soal-soal latihan beserta penjelasan dan kunci jawaban, dan soal uji kompetensi.

Pada tahap ini teridentifikasi standar kompetensi untuk materi kinematika gerak lurus adalah memahami gejala-gejala alam melalui pengamatan, kompetensi dasarnya yaitu menganalisis data percobaan gerak lurus beraturan dan gerak lurus berubah beraturan serta penerapannya dalam kehidupan seharihari.

Berdasarkan desain cara penyajian nilai karakter, diperoleh bahwa nilai kabajikan religious (seperti berdo'a sebelum belajar, bersyukur ketika sudah memahami suatu konsep, dan lain sebagainya), jujur, toleransi, disiplin, kerja keras, patriotisme, cinta damai, peduli lingkungan sosial, dan tanggung jawab perlu disisipkan dalam permulaan program maupun materi dengan cara yang bersifat ajakan.

Berdasarkan hasil identifikasi materi, maka didapatkan desain simulasi yang disajikan melalui animasi dan simulasi praktikum. Adapun desain simulasi yang dihasilkan yaitu simulasi untuk menjelaskan konsep gerak, jarak, dan perpindahan, kelajuan dan kecepatan, gerak lurus beraturan (GLB) dan gerak lurus berubah beraturan (GLBB) serta grafik hubungan jarak terhadap waktu $(s-t)$, perpindahan terhadap waktu $(\vec{s}-t)$, kelajuan terhadap waktu $(v-t)$, kecepatan terhadap waktu $(\vec{v}-t)$, dan percepatan terhadap waktu $(\vec{a}-t)$,dan simulasi ticker timer pada percobaan GLB dan GLBB dipercepat. Setelah dihasilkan desain simulasi, kemudian diperoleh spesifikasi multimedia yang juga dijadikan sebagai acuan untuk menyusun instrumen penilaian kelayakan multimedia.

3) Develop(pengembangan), tahap selanjutnya yaitu pengembangan produk yang dibuat berdasarkan naskah/desain materi, nilai karakter, dan tujuan pembelajaran yang telah dirancang sebelumnya, dengan menggunakan software macromedia flash. Produk multimedia interaktif hasil pengembangan pada tahap ini disebut sebagai prototipe I.

Pada tahap develop ini juga dilakukan pengujian program yang telah dikembangkan. Adapun tahap-tahap pengujiannya meliputi:uji internal dan uji eksternal.

a) Hasil uji internal.

Pengujian internal merupakan uji kualitas produk, yang dilakukan oleh ahli desain produk, isi / materi pembelajaran, dan pembelajaran nilai karakter. Ahli desain dipercayakan pada salah seorang dosen perguruan tinggi negeri di Lampung untuk menilai program dalam aspek: komunikasi, desain teknis, dan format tampilan. Dan dari hasil angket yang diisi oleh ahli desain, didapatkan data bahwa informasi pada kemasan luar sudah sesuai, pemakaian font (ukuran, warna, dan variasi jenis) disetiap 
tampilan sudah sesuai, keproporsionalan perbandingan huruf yang diunakan dalam multimedia sudah sesuai, ukuran ilustrasi baik animasi maupun gambar sudah sesuai, fungsi, letak dan bentuk tombol dalam sudah sesuai, multimedia yang dikembangkan sudah rapih dan kombinasi warnanya sesuai, sistem operasi baik kompatibilitas, kecepatan akses sudah sesuai, mudah dan relevan terhadap sasaran pengguna.

Pengujian internal berikutnya yaitu menguji program dalam aspek isi/materi pembelajaran yang dipercayakan kepada ahli isi/materi pembelajaran yakni seorang guru SMP bidang pengajaran fisika. Hasil angket yang diisi oleh ahli isi/materi pembelajaran, didapatkan data bahwa sajian dalam multimedia ini sudah memvariasikan materi sesuai dengan kompetensi dan kemampuan berpikir yang diharapkan, judul dan sasaran pengguna jelas, menuntut pengguna untuk dapat belajar mandiri, penjelasan materi konseptual dan penjelasan materi praktis sudah tepat, kemenarikan materi dapat memotivasi pengguna, rumusan dan petunjuk mengerjakan soal latihan/tes sudah jelas, tingkat kesulitan tes sesuai, feedback atas jawaban pengguna sudah tepat, fakta dan fenomena yang ada sudah efisien dan sesuai dengan kenyataan, sajian gambar atau ilustrasi efisien dalam meningkatkan pema-haman siswa, istilahistilah yang digunakan sesuai dengan yang berlaku pada pelajaran IPA khususnya bidang fisika, materi/contoh-contoh yang disajikan mencerminkan peristiwa dan kejadian terkini, referensi yang dirujuk merupakan yang terbaru, dan penulisan pustakanya pun sesuai dengan kaidah penulisan karya ilmiah.

Pengujian pada aspek nilai-nilai karakter yang terkandung di dalam program dipercayakan pada salah seorang dosen di Universitas Pamulang.Pengujian ini diperoleh hasil bahwa nilai-nilai karakter yang terkandung dalam multimedia interaktif hasil pengembangan sudah disajikan dengan baik.

Hasil uji internal pada prototipe I ini kemudian dilakukan perbaikan berdasarkan kritik dan saran yang ada, dan hasil perbaikannya diberi nama prototipe II yang kemudian diuji secara eksternal.

b) Hasil uji eksternal

Uji coba produk berikutnya yaitu uji coba untuk mengetahui tingkat kemenarikan, kemudahan, kemanfaatan, dan keefektifan mencapai kemampuan berfikir tingkat tinggi yang diharapkan.Uji coba ini juga bertujuan untuk memperoleh data di lapangan guna perbaikan produk. Uji ini dilakukan melalui tiga tahapan, yaitu: uji satu-satu, uji kelompok, dan uji lapangan.

Uji satu-satu dikenakan pada dua orang sampel siswa dibelajarkan dengan menggunakan prototipe II, dan kemudian dimintai pendapatnya tentang prototipe ini. Hasil uji satu-satu diperoleh rerata skor 3,54 dengan kriteria sangat menarik, rerata skor 3,50 dengan kriteria sangat mudah digunakan, dan rerata skor 3,42 dengan kriteria sangat bermanfaat.

Pengujian kelompok yang dikenakan pada lima orang sampel siswa yang dipilih secara acak. Lima orang siswa yang terpilih kemudian diberi perlakuan dengan memberikan pembelajaran materi kinematika gerak lurus menggunakan prototipe II, kemudian dimintai pendapatnya. Hasil uji kelompok diperoleh rerata skor 3,42 dengan kriteria sangat menarik; rerata skor 3,03 dengan kriteria mudah digunakan; dan rerata skor 3,30 dengan kriteria sangat bermanfaat.

Pengujian lapangan dilakukan dengan cara eksperimen pembelajaran menggunakan multimedia interaktif yang telah dikembangkan. Eksperimen ini menggunakan desain static group comparison menurut Ary, Donald (2010) dengan dua kelompok sampel, di mana kelompok pertama dibelajarkan tanpa menggunakan program hasil pengembangan, dan kelompok kedua (kelas eksperimen) dibelajarkan dengan menggunakan produk yang telah dikembangkan, kemudian dilakukan post-test untuk mengukur kemampuan berpikir tingkat tinggi peserta didik.

Hasil pengujian lapangan ini diperoleh rata-rata nilai kemampuan berpikir tingkat tinggi kelompok kontrol sebesar 38,636 sedangkan kelompok eksperimen sebesar 62,083, yang berarti bahwa kelompok peserta didik yang dibelajarkan dengan menggunakan multimedia hasil pengembangan ini memiliki rata-rata kemampuan berpikir tingkat tinggi yang lebih unggul sebesar 23,447 dibandingkan dengan kelompok peserta didik yang tidak menggunakan multimedia hasil pengembangan ini. Dan berdasarkan hasil pengujian independent sample t-test, diperoleh nilai Sig. (2-tailed) sebesar 0,016 <0,05, sehingga dapat disimpulkan bahwa pada tingkat kepercayaan 95\% rata-rata nilai kelompok eksperimenlebih tinggi secara signifikan dibandingkan dengan rata-rata nilai kelompok control. Hasil lengkap pengujian independent sample t-test dapat dilihat pada Tabel 1 berikut. 
TABEL 1

HASIL PENGUJIAN INDEPENDENT SAMPLES TEST

\begin{tabular}{|c|c|c|c|c|c|c|}
\hline & \multicolumn{2}{|c|}{$\begin{array}{c}\text { Levene's Test for Equality } \\
\text { of Variances }\end{array}$} & \multicolumn{3}{|c|}{ t-test for Equality of Means } \\
\hline & & $F$ & Sig. & $t$ & $d f$ & Sig. (2-tailed) \\
\hline \multirow[t]{2}{*}{ Nilai } & $\begin{array}{l}\text { Equal variances } \\
\text { assumed }\end{array}$ & 1.094 & .312 & -2.706 & 15 & .016 \\
\hline & $\begin{array}{l}\text { Equal variances not } \\
\text { assumed }\end{array}$ & & & -2.413 & 7.638 & .044 \\
\hline
\end{tabular}

Perlu dipahami bahwa, pada pengujian lapangan ini hanya mengukur keefektifan produk sebagai bahan pembelajaran dalam aspek kognitif saja, tidak dilakukan pengukuran peningkatan nilai karakter, karena pengukuran ini dirasa memerlukan waktu yang relatif lama.Akan tetapi, dengan adanya program ini diharapkan dapat merangsang dan memotivasi peserta didik untuk menumbuhkan nilai-nilai karakter sesuai jati diri bangsa Indonesia.

Berdasarkan hasil pada setiap uji yang dilakukan, multimedia hasil pengembangan dinyatakan layak dan efektif digunakan sebagai sumber sekaligus media pembelajaran.Hal itu dikarenakan multimedia ini telah mengalami beberapa tahapan uji coba dan revisi secara berkala.Dan berdasarkan data diperoleh bahwa secara keseluruhan multimedia ini memiliki desain, isi/materi pembelajaran, dan nilai karakter yang bagus dan sesuai dengan sasaran pengguna.

\section{4) Disseminate (penyebaran).}

Pada tahap ini hanya dilakukan penyebarluasan dan penerapan akan program yang telah dibuat sebagai salah satu sumber maupun media pembelajaran pada SMP Negeri 2 Trimurjo dan salah satu instansi pendidikan swasta di Tangerang selatan.

\section{PENUTUP}

Salah satu upaya untuk memperbaiki kualitas pendidikan, yaitu dengan peningkatan kualitas media pembelajaran itu sendiri.Berdasarkan hasil pada setiap uji yang dilakukan, multimedia pembelajaran karakter hasil pengembangan dinyatakan layak dan efektif digunakan sebagai sumber sekaligus media pembelajaran untuk meningkatkan kemampuan berpikir tingkat tinggi.

Nilai-nilai karakter yang terkandung dalam multimedia interaktif hasil pengembangan sudah disajikan dan masuk kategori baik. Produk ini tidak sampai pada pengujian keefektifan peningkatan nilai karakter peserta didik, akan tetapi dengan adanya program ini diharapkan dapat merangsang dan memotivasi peserta didik untuk menumbuhkan nilainilai karakter sesuai jati diri bangsa Indonesia.

\section{REFERENSI}

[1] A., Doni Koesoema. (2010). Pendidikan Karakter; Strategi Mendidik Anak di Zaman Global.Jakarta: Grasindo

[2] Anderson, L.W. (Ed.), Krathwohl, D.R. (Ed.), Airasian, P.W., Cruikshank, K.A., Mayer, R.E., Pintrich, P.R., Raths, J., \& Wittrock, M.C. (2001). A taxonomy for learning, teaching, and assessing: A revision of Bloom's Taxonomy of Educational Objectives (Complete edition). New York: Longman.

[3] Ary, Donald, Jacobs, L.C., \& Sorensen, Chris. (2010). Introduction to Research in Education 8th Edition. Canada: Wadsworth, Cengage Learning.

[4] Asyhar, Rayandra. (2011). Kreatif Mengembangkan Media Pembelajaran. Jakarta: Gaung Persada (GP) Press.

[5] Krathwohl, D. R. (2002). A revision of Bloom's Taxonomy: an overview - Theory Into Practice,College of Education, The Ohio State University Learning Domains or Bloom's Taxonomy: The Three Types of Learning. tersedia di www.nwlink.com/ donclark/hrd/bloom.html

[6] Muhtadi, Ali. (2006). Penanaman Nilai-nilai agama dalam pembentukan sikap dan perilaku siswa SD Islam terpadu Luqman Al-Hakim Yogyakarta.Jurnal Penelitian dan Evaluasi Pendidikan, Nomor 1, VIII.

[7] Mukhibat. (2012).Reinventing Nilai-Nilai Islam, Budaya, dan Pancasila dalam Pengembangan Pendidikan Karakter. Jurnal Pendidikan Islam. Volume I, Nomor 2, Halaman: 247265.

[8] Rofiah, Emi., Siti, Nonoh. \& Yusliana, Elvin. (2013). "Penyusunan Instrumen Tes Kemampuan Berpikir Tingkat Tinggi Fisika pada Siswa SMP”. Jurnal Pendidikan Fisika, 1 (2) Halaman: 17-22.

[9] Sanjaya, Rangga. (2016). Multimedia Interaktif Pelatihan Service Excellent Menggunakan Pendekatan Story Based Learning. Jurnal Informatika, Vol.III, No.1. Halaman: 100106.

[10] Susilana, Rudi dan Cepi Riyana. (2007). Media Pembelajaran. Bandung: CV Wacana Prima.

[11] Thiagarajan, S., Semmel, D.S \& Semmel,M.L (1974). Instructional development for training teacher of exeptional childre. Minnesota: Indiana University.

[12] Wina Sanjaya. (2009). Strategi pembelajaran berorientasi standar proses pendidikan.Jakarta : Kencana Prenada Media Group. 